\title{
Environmental, Health, and Safety Issues of Sodium-Sulfur Batteries for Electric and Hybrid Vehicles
}

\section{Volume I: Cell and Battery Safety}

J. M. Ohi

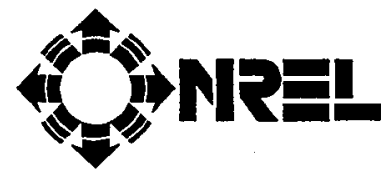

National Renewable Energy Laboratory

(formerly the Solar Energy Research Institute) 1617 Cole Boulevard Golden, Colorado 80401-3393

A Division of Midwest Research Institute

- Operated for the U.S. Department of Energy under Contract No. DE-AC02-83CH10093

Prepared under Task No. AS015440

September 1992 


\section{NOTICE}

This report was prepared as an account of work sponsored by an agency of the United States government. Neither the United States government nor any agency thereof, nor any of their employees, makes any warranty, express or implied, or assumes any legal liability or responsibility for the accuracy, completeness, or usefulness of any information, apparatus, product, or process disclosed. or represents that its use would not infringe privately owned rights. Reference herein to any specific commercial product, process, or service by trade name, trademark, manufacturer, or otherwise does not necessarily constitute or imply its endorsement, recommendation, or favoring by the United States government or any agency thereof. The views and opinions of authors expressed herein do not necessarily state or reflect those of the United States government or any agency thereof.

Printed in the United States of America

Available from:

National Technical Information Service

U.S. Department of Commerce

5285 Port Royal Road

Springfield, VA 22161

Price: Microfiche A01

Printed Copy $\mathrm{AO3}$

Codes are used for pricing all publications. The code is determined by the number of pages in the publication. Information pertaining to the pricing codes can be found in the current issue of the following publications which are generally available in most libraries: Energy Research Abstracts (ERA); Government Reports Announcements and Index (GRA and I); Scientific and Technical Abstract Reports (STAR); and publication NTIS-PR-360 available from NTIS at the above address. 


\section{Preface}

This report is the first of four volumes that identify and assess the environmental, health, and safety issues involved in using sodium-sulfur $(\mathrm{Na} / \mathrm{S})$ battery technology as the energy source in electric and hybrid vehicles that may affect the commercialization of $\mathrm{Na} / \mathrm{S}$ batteries. This and the other reports on recycling, shipping, and vehicle safety are intended to help the Electric and Hybrid Propulsion Division of the Office of Transportation Technologies in the U.S. Department of Energy (DOE/EKP) determine the direction of its research, development, and demonstration (RD\&D) program for Na/S battery technology. ${ }^{1}$ The reports review the status of Na/S battery RD\&D and identify potential hazards and risks that may require additional research or that may affect the design and use of $\mathrm{Na} / \mathrm{S}$ batteries.

These reports were prepared by the Analytic Studies Division of the National Renewable Energy Laboratory and are one part of DOE/EHP's RD\&D program to work with industry to commercialize Na/S batteries. For example, data and information obtained through these reports will assist the DOE/EHP implement recommendations made by participants at government-industry meetings on sodium-beta batteries sponsored by the DOE/EHP [1]. The reports may also assist the DOE/EHP and the Ad Hoc Electric Vehicle Battery Readiness Working Group coordinate the RD\&D needed to commercialize Na/S and sodium metal chloride battery technologies. ${ }^{2}$

For these reports, it is important to define hazard and risk. A hazard is a source of risk, a substance or action that can cause harm. Risk, on the other hand, is the possibility of suffering harm from a hazard [2]. While the chemical and thermal hazards of elemental sodium are substantial, the risks involved in using sodium in a battery can be minimized through careful design, engineering, and testing. These reports on $\mathrm{Na} / \mathrm{S}$ battery technology do not constitute a formal risk analysis, which usually includes estimates of the amounts, frequencies, and locations of the release of hazandous materials; the duration of exposures to these agents; estimates of the percentage of the population exposed and of dosage-response relationships; and a quantitative estimate of risk [2]. These reports provide a qualitative analysis of hazards and risks that must be addressed before $\mathrm{Na} / \mathrm{S}$ batteries can be deployed on a commercial scale. These reports are intended to help DOE/EHP set management priorities for the RD\&D of $\mathrm{Na} / \mathrm{S}$ battery technology by identifying potential hazards and risks, by reviewing RD\&D in progress to address these hazards and risks, and by recommending RD\&D needed to help minimize these hazards and risks.

This volume covers cell design and engineering as the basis of safety for $\mathrm{Na} / \mathrm{S}$ batteries and describes and assesses the potential chemical, electrical, and thermal hazards and risks of $\mathrm{Na} / \mathrm{S}$ cells and batteries as well as the RD\&D performed, under way, or needed to address these hazards and risks. The report is based on a review of the literature and on discussions with experts at DOE, national laboratories and

'These assessments are concemed with $\mathrm{Na} / \mathrm{S}$ batteries used as traction batteries for electric and hybrid vehicles and are not concemed with stationary energy storage.

2 The Ad Hoc Electric Vehicle Battery Readiness Working Group consists of leading scientists and program managers from government agencies, battery developers, automobile manufacturers, and the chemical processing industry. 
agencies, universities, and private industry. Subsequent volumes will address environmental, health, and safety issues involved in shipping cells and batteries, using batteries to propel electric vehicles, and recycling and disposing of spent batteries.

The remainder of this volume is divided into two major sections on safety at the cell and battery levels. The section on $\mathrm{Na} / \mathrm{S}$ cells describes major components and potential failure modes, design, life testing and failure testing, thermal cycling, and the safety status of $\mathrm{Na} / \mathrm{S}$ cells. The section on batteries describes battery design, testing, and safety status. Additional EH\&S information on Na/S batteries is provided in the appendices.

I am indebted to many people who helped me obtain information and reviewed drafts of this volume. I am especially indebted to J. Braithwaite of Sandia National Laboratories who helped me understand some of the technical intricacies of $\mathrm{Na} / \mathrm{S}$ battery technology and who patiently reviewed several drafts of this volume. I would also like to thank R. MacDowall of Idaho National Engineering Laboratory, J. Smaga of Argonne National Laboratory, E. Dowgiallo, Jr., and K. Heitner of DOE/EHP, H. Haskins of Ford Motor Company and the USABC, and R. Swaroop of EPRI for reviewing a draft of this volume and offering helpful technical suggestions on the text. I am also indebted to J. Rasmussen of Beta Power, Inc., for providing me technical insights into $\mathrm{Na} / \mathrm{S}$ batteries, especially those concerning the beta"-alumina electrolyte. I also thank W. Fischer of ABB and P. Binden of CSPL for sending me information and publications on safety issues and M. Brada (then) of the Colorado School of Mines for assisting me in research. Finally, I thank D. O'Hara of DOE/EHP for his leadership and support in directing and sponsoring the EH\&S program and these assessments. 


\section{Table of Contents}

Page No.

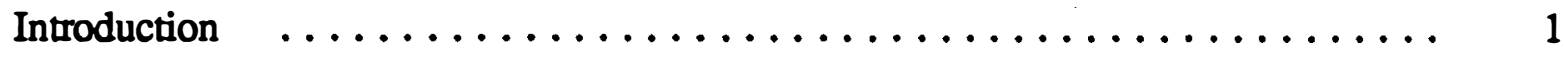

Intrinsic Material Hazards ......................... 3

$\mathrm{Na} / \mathrm{S}$ Cell Components and Failure Modes $\ldots \ldots \ldots \ldots \ldots$

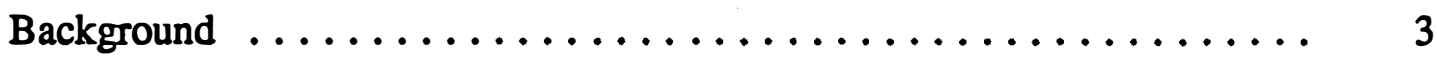

Beta"-Alumina Electrolyte $\ldots \ldots \ldots \ldots \ldots \ldots \ldots \ldots \ldots \ldots \ldots$

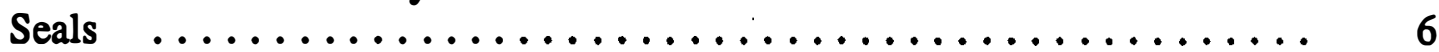

Alpha-Alumina-Beta "-Alumina Glass ............... 6

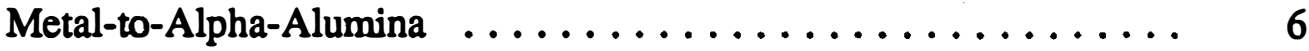

Cell Container-Sulfur Electrode ................ 7

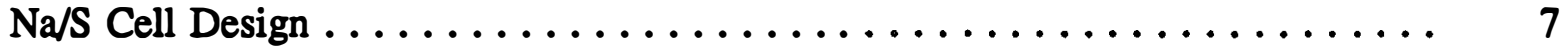

Cell Safety Testing $\ldots \ldots \ldots \ldots \ldots \ldots \ldots \ldots \ldots \ldots \ldots \ldots \ldots \ldots \ldots \ldots \ldots \ldots$

Life Testing $\ldots \ldots \ldots \ldots \ldots \ldots \ldots \ldots \ldots \ldots \ldots \ldots \ldots \ldots \ldots \ldots$

Failure Testing $\ldots \ldots \ldots \ldots \ldots \ldots \ldots \ldots \ldots \ldots \ldots \ldots \ldots \ldots$

Thermal (Freeze-Thaw) Cycling ................... 13

Safety Status of $\mathrm{Na} / \mathrm{S}$ Cells $\ldots \ldots \ldots \ldots \ldots \ldots \ldots \ldots \ldots \ldots \ldots$

Battery Safety . . . . . . . . . . . . . . . . . . . . . . . 14

Battery Design $\ldots \ldots \ldots \ldots \ldots \ldots \ldots \ldots \ldots \ldots \ldots \ldots \ldots \ldots$

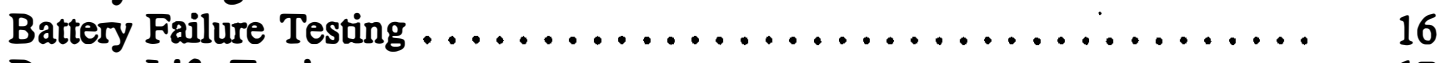

Battery Life-Testing . . . . . . . . . . . . . . . . . . . 17

Safety Status of $\mathrm{Na} / \mathrm{S}$ Batteries $\ldots \ldots \ldots \ldots \ldots \ldots$

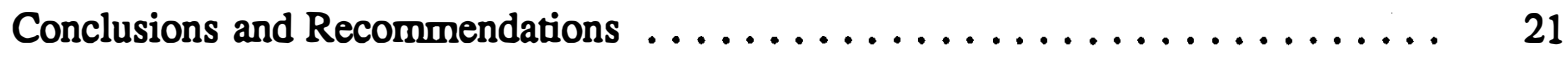

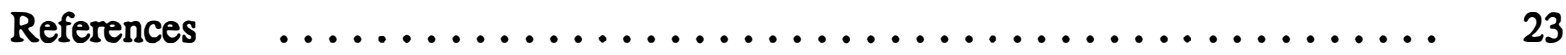

Appendix A - Chemical Hazards of Sodium-Sulfur Batteries . . . . . . . . . A A-1

Appendix B - Toxicities and Reactivities of Chemical Elements and Compounds Potentially Associated with the use

of $\mathrm{Na} / \mathrm{S}$ Batteries . . . . . . . . . . . . . . . . 
TP-4678

\section{List of Tables}

Page No.

Table 1 - Hazardous Chemical Species Associated with

a Sodium-Sulfur Battery .......................... 4

Table $2-\quad$ Cell Component Stability $\ldots \ldots \ldots \ldots \ldots \ldots$

Table 3 - Program for Safety Tests on Sodium-Sulfur Batteries

Part 1: Normal Use ........................ 18

Table 4 - $\quad$ Program for Safety Tests on Sodium-Sulfur Batteries

Part 2: Safety During/After Accidents ................. 19

\section{List of Figures}

Page No.

Figure $1-\quad$ The $\mathrm{Na}_{2} \mathrm{~S} / \mathrm{S}$ phase diagram $\ldots \ldots \ldots \ldots \ldots \ldots \ldots \ldots \ldots$

Figure $2-\quad$ The $A B B$ cell design $\ldots \ldots \ldots \ldots \ldots \ldots \ldots \ldots$

Figure $3-\quad$ The CSPL cell design $\ldots \ldots \ldots \ldots \ldots \ldots \ldots \ldots$ 


\section{Introduction}

A Na/S battery consists of three major subsystems: a large number of mechanically and electrically interconnected cells, a thermal enclosure to maintain an operating temperature range of $300^{\circ}-350^{\circ} \mathrm{C}$, and a thermal management system for initial heating of the battery and for removing waste heat [3]. System components peripheral to the battery itself, such as the battery controller, affect battery safety but will not be considered in this report.

The major components of the $\mathrm{Na} / \mathrm{S}$ cell are a solid ceramic electrolyte of beta"-alumina, liquid electrodes of sodium and sulfur, and a container [4]. The electrolyte is usually sealed to an alpha-alumina component that provides an insulating surface for the seals on the metal current-collectors. During most of the discharge two liquid phases exist (Figure 1), and the extent of the cell reaction possible varies according to the temperature of operation [5]. The theoretical specific energy normally quoted for the $\mathrm{Na} / \mathrm{S}$ cell, $760 \mathrm{Wh} / \mathrm{kg}$, is calculated for the reaction proceeding to an average composition of $\mathrm{Na}_{2} \mathrm{~S}_{3}$ :

$$
2 \mathrm{Na}+3 \mathrm{~S}=\mathrm{Na}_{2} \mathrm{~S}_{3}
$$

The electromotive force (EMF) of the cell at the normal operating temperature of $350^{\circ} \mathrm{C}$ is $2.076 \mathrm{~V}$, which declines to $1.74 \mathrm{~V}$ at a polysulfide composition corresponding to $\mathrm{Na}_{2} \mathrm{~S}_{3}$ [6].

Development of the Na/S cell, first announced by the Ford Motor Company in 1966, was made possible by the discovery of the high ionic conductivity of sodium ions in beta-alumina ceramic [6]. In the intervening 25 years, $\mathrm{Na} / \mathrm{S}$ cells have undergone continual development, and the two principal manufacturers of Na/S batteries for electric vehicles, Asea Brown Boveri (ABB) and Chloride Silent Power Limited (CSPL) have made many changes to both cell and battery design to improve safety. This report describes the evolution of cell designs at CSPL and ABB to address safety issues and identifies cell design issues requiring additional RD\&D. The report also evaluates safety issues involved in interconnecting cells to form modules and batteries.

Although electrical integrity at the battery level is critical and electrical hazards associated with a Na/S (or any high-energy) battery must be acknowledged, the key (and the emphasis of this assessment) for the safe operation of $\mathrm{Na} / \mathrm{S}$ batteries resides in the chemical, thermal, and structural integrity of the individual cells that make up the battery. Due to the large number of cells, the temperature-dependent nature of the chemical reactions, and the potential for cell-to-cell interactions, however, safety testing at the cell level cannot always be extrapolated to the battery level. In this report, a clear distinction is maintained between cell and battery safety as well as between cell and battery testing. A further distinction must be made between safety under normal operating conditions and safety under catastrophic events such as collisions. The latter is also discussed in the sections on failure testing of cells and batteries and in the volume on vehicle safety issues. 


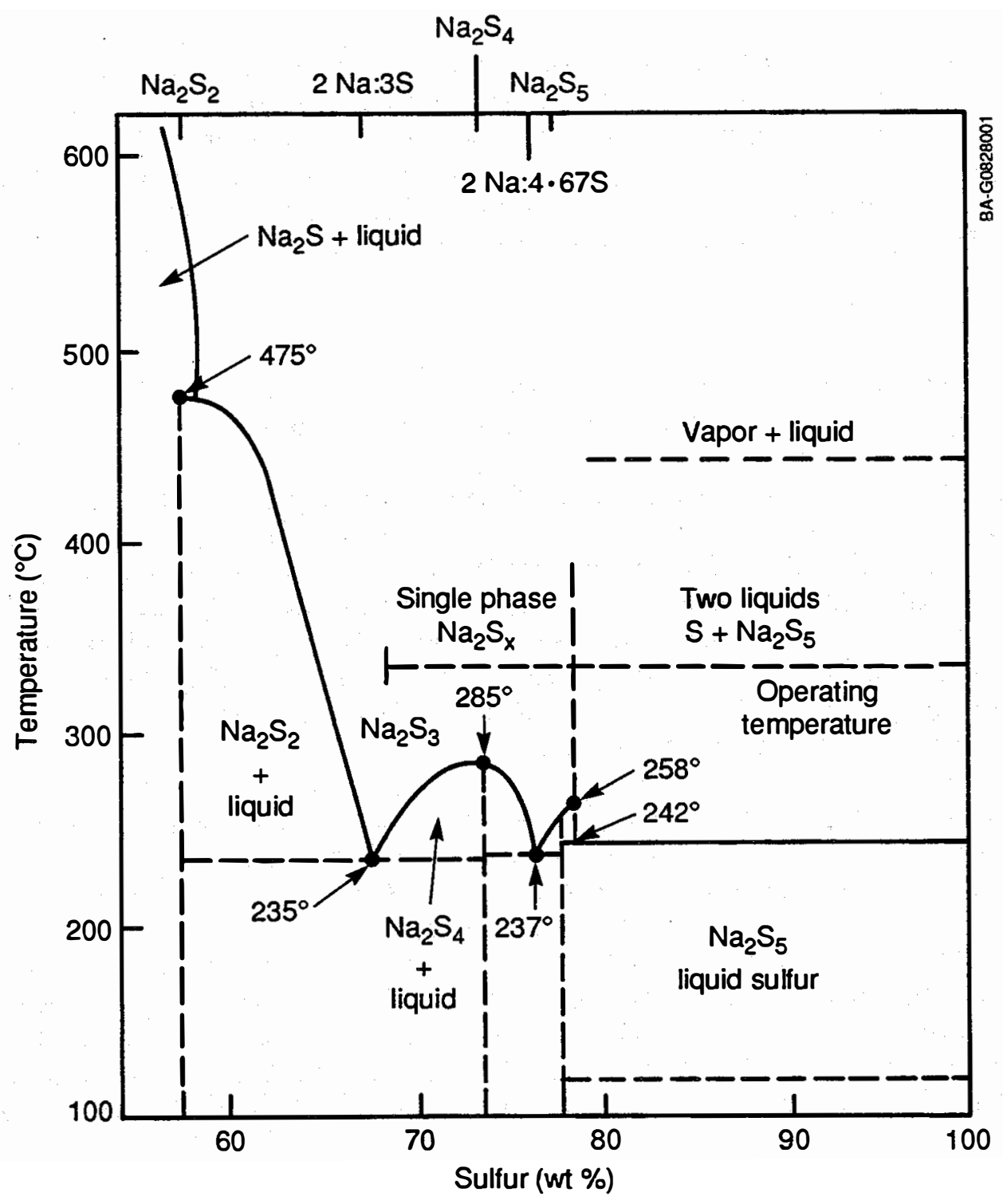

Figure 1. The $\mathrm{Na}_{2} \mathrm{~S} / \mathrm{S}$ phase diagram

Source: Adapted from Ref. 5. 


\section{Intrinsic Material Hazards}

A battery by definition is a source of direct-current voltage and involves construction of an electrochemical device to allow controlled interaction of reactive materials. The use of reactive materials is, also by definition, a hazandous enterprise. In the case of $\mathrm{Na} / \mathrm{S}$ batteries, the hazards of using elemental sodium and sulfur, which are well known as reactive materials, are accentuated by the need to maintain them in a molten state (about $350^{\circ} \mathrm{C}$ ) separated by a thin ceramic electrolyte. The chemical and thermal hazards due to primary reactions of materials used in the $\mathrm{Na} / \mathrm{S}$ battery are summarized in Table 1 and Appendix A. Again, it should be stressed that hazards, not risks, are discussed in this section. Further analysis is required to derive a quantitative estimate of risk from a particular hazard. For example, chromium sulfide, a potential product from corrosion of the cell container, is toxic, but its very low concentration and insolubility substantially removes the risk of injury from this particular hazard.

Hazards are not only associated with chemical reactions that occur within the cell, as in the example of chromium sulfide, but also when contaminants or outside agents are inadvertently introduced, for example, as a result of an accident or collision. Hazards associated with sodium include its reaction with water. This reaction is highly exothermic, usually explosive, and produces hydrogen gas and sodium hydroxide [6]. These reaction products can also be hazards. Hydrogen in the presence of oxygen is highly explosive, and sodium hydroxide is poisonous upon ingestion and can cause severe chemical burns [6]. The direct reaction of molten sodium and molten sulfur is a fire hazard and produces sodium sulfide. Sodium reacts exothermically with dozens of other elements and compounds. It is spontaneously flammable when heated in air and will emit sodium monoxide, a toxic gas [6]. If sodium bums on concrete, there could be spalling of concrete and splattering of metallic sodium, concrete, and caustic chemical compounds. In the presence of water, sodium sulfides can produce hydrogen sulfide, an explosive and poisonous gas.

Sulfur is not as chemically reactive as sodium, but there are significant hazards associated with its use. Sulfur is flammable and produces sulfur dioxide, a toxic gas and a tumorigen, when bumed [6]. The reaction of sodium and sulfur produces sodium polysulfides, which are highly corrosive and can corrode the metallic housing of the cell to form chromium sulfide described above. The elements and compounds discussed in this and the previous paragraph are the principal sources of the chemical, physical, and thennal hazards of reactants and reaction products possible from the use or abuse of Na/S cells. The toxicities of these elements and compounds are given in Appendix B.

\section{$\mathrm{Na} / \mathrm{S}$ Cell Components and Failure Modes}

\section{Background}

The safety of $\mathrm{Na} / \mathrm{S}$ batteries depends on how well hazards, which are intrinsic in the reactivity of the materials used in the $\mathrm{Na} / \mathrm{S}$ cell, are accounted for in the design of cells and batteries. A typical 50-kWh $\mathrm{Na} / \mathrm{S}$ battery to power an electric vehicle contains about $40 \mathrm{~kg}$ of molten sodium and $60 \mathrm{~kg}$ of molten sulfur at approximately $350^{\circ} \mathrm{C}$. The key to safe perfornance under normal operating conditions is to minimize the occurrence of large thermal excursions by: (1) not to allowing significant quantities of 
Table 1. Hazardous Chemical Species Associated with a Sodium-Sulfur Battery

Species

Liquid sodium

Liquid sulfurt

Sodium polysulfideb

Sodium oxide

Sodium hydroxide

Sulfur dioxide

Chromic sulfide

Hydrogen sulfide
Safety Concem

Hot, toxica , reactive, bums in air, reacts violently with liquid sulfur, reacts explosively with water

Hot, bums in air, reacts violently with liquid sodium, contaminated with sodium sulfide and sodium polysulfide

Toxic, can explode on percussion or rapid heating

Toxic, damages human skin and mucous membranes

Toxic, damages human skin and mucous membranes

Toxic, heavier than air

Toxic, not appreciably soluble in water

Toxic, lethal in low dosage, explosive

- "Toxic" indicates a toxicity rating of 3 as defined in N. I. Sax, Dangerous Properties of Industrial

Materials, 6th Edition, Van Nostrand Reinhold, 1984.

b The sulfur phase contains various sulfur polymers, usually designated as polysulfur. Polysulfur reacts with sodium to form sodium polysulfide.

c Chromium ion may be formed in the sulfur electrode from corrosion of chromium. 
sodium and sulfur to interact, (2) containing all molten reactants and products, and (3) preventing largescale electrical short-circuiting. The approach taken to date is to subdivide the sodium and sulfur into many small, sealed cell packages [5]. Safety of the $\mathrm{Na} / \mathrm{S}$ battery then becomes dependent, to a large part, on the safety of each cell.

Cell safety has been an important part of $\mathrm{Na} / \mathrm{S}$ research since the first paper on cell safety was published in 1975 by Hames and Tilley who defined a safe cell as a "cell which, under all but the most improbable conditions, did not allow its reactive contents to escape in the event of cell failure or accident" [5]. Tilley defines three general principles of cell safety [5]:

1. Minimize the quantity of sodium immediately available for reaction after beta"- alumina failure

2. Separate the bulk of cell reactants and restrict the flow of bulk sodium to the reaction site,

3. Protect the outer cell case against corrosion by sodium polysulfides at elevated temperatures (for a sodium-core cell).

\section{Beta"-Alumina Electrolyte}

The most hazardous situation at the cell level is created by the direct reaction of sodium and sulfur, during which temperature increases of greater than $2000^{\circ} \mathrm{C}$ accompanied by correspondingly high internal pressures are possible [5]. Fracture of the beta"-alumina electrolyte, then, is the most serious failure mode, and to prevent cell rupture, it becomes essential to limit the rise in cell temperature in case of electrolyte fracture [5].

The temperature rise due to the immediate reaction of sodium and sulfur after electrolyte fracture will be very rapid and governed by three factors: (1) the amount of reactants available, (2) the overall heat capacity of the battery system, and (3) the rate of heat dissipation [5]. Of these factors, only the first, the amount of reactants, provides a useful way to control temperature rise. For example, to increase the heat capacity of the system sufficiently to limit the temperature increase generated by the production of $1 \mathrm{~kg}$ of $\mathrm{Na}_{2} \mathrm{~S}_{3}$ to $200^{\circ} \mathrm{C}$, almost $4 \mathrm{~kg}$ of stainless steel would be required. Furthermore, although heat can be dissipated to surrounding cells, heating of adjacent cells could also propagate cell failure [5]. Minimizing the amounts of sodium and sulfur that can react immediately becomes the first principle of cell safety.

The amount of bulk sodium available at the surface of the beta"-alumina electrolyte controls the rate of heat generated by the secondary reaction of sodium and sulfur upon electrolyte fracture. If the minimum flow rate of sodium to the electrolyte, which is set by the maximum discharge rate under normal operating conditions, is not greatly exceeded, the heat should be dissipated over a reasonable period of time by the heat balance designed into the battery system [5]. Cell design to minimize the flow of sodium to the electrolyte surface is described below in the section on $\mathrm{Na} / \mathrm{S}$ cell design.

Even if the increase in cell temperature upon electrolyte failure could be limited, failure propagation could occur if seals separating the reactants fail or if the outer cell container is breached through corrosion by sodium polysulfides at high a temperature [5]. Thus it is critical for cell safety to protect both the seals and the outer cell container against corrosion. 


\section{Seals}

The beta"-alumina electrolyte separates compartments containing liquid sodium and sulfur/sodium polysulfides, highly reactive and corrosive materials that must be sealed from each other and from the atmosphere. The compartments must also be electrically isolated from each other. Electrical conductivity and durability largely determine the selection of materials and fabrication techniques for the electrolyte; consequently, methods to seal the cell are limited because these methods must be compatible with the material properties of the electrolyte [5]. Seals are a critical component of cell structure both for reliability and safety considerations, because they can limit the maximum temperature and pressure the cell can attain [5]. If the seals fail, reactants can leak out and breach the cell container, which in tum can lead to electrical short circuiting of other cells in the battery.

\section{Alpha-Alumina-Beta"-Alumina Glass}

Most cell designs use an alpha-alumina collar (also called header or top cap) to provide electrical and ionic insulation between the two metallic current collectors. Usually, the beta"-alumina electrolyte is bonded to the alpha-alumina by a glass sealant. Many configurations for this seal are used. The glass material must provide a hermetic seal between the header and the electrolyte and withstand attack by liquid sodium as well as an occasional freeze-thaw cycle. Ideally, the glass seal should be stress-free at the operating temperature of the cell and have a net radial compressive stress at room temperature [5]. The properties of glass used for seals should include [7]:

- Thermodynamic stability in $\mathrm{Na}, \mathrm{S}$, and sodium polysulfides

- Low sealing temperature to minimize interdiffusion of electrolyte and glass components

- Thermal expansion coefficient matching those of the electrolyte and alpha-alumina seal

- Thermal stability at cell operating temperature

- Ease of fabrication.

According to Sudworth and Tilley [5], an enormous amount of effort has been devoted to developing this seal, and the seal is "almost fully developed now in a satisfactory form ...." Several cells with a aluminoborosilicate glass seal used in all standard production cells made by CSPL have remained intact (as of 1991) for more than 8,800 electrical cycles in more than 62,000 hours [8].

\section{Metal-to-Alpha-Alumina}

Early metal-to-alpha-alumina seals were mechanical compression devices using a variety of gasket materials and clamping methods [5]. Contemporary seals use a thermocompression bonding technique in which the simultaneous application of heat and pressure creates atomic interdiffusion of a metal and a ceramic. For example, in its PB cell design, CSPL has used a direct ceramic-to-metal bonded seal for the sodium electrode closure and a metal-aluminum interstrate seal for the sulfur electrode closure [9]. The upper temperature limit for present seals is about $650^{\circ} \mathrm{C}$ [5]. 


\section{Cell Container-Sulfur Electrode}

The third principle of cell safety, according to Sudworth and Tilley [5], is to protect the outer container from corrosion by sodium polysulfides at high temperatures. In a sodium-core cell, the outer container houses the sulfur electrode and also serves as the positive current collector. The formidable material requirements for the container-electrode include good corrosion resistance, high conductivity, ease of fabrication, low weight, and low cost; consequently, no single material that combines all of these properties has been found [5]. Corrosion resistance is required not only to maintain mechanical integrity of the cell, but also to prevent degradation of cell performance because corrosion products can increase cell resistance [5]. Most battery developers have tried to meet these difficult material requirements by using composite materials, usually an inexpensive substrate, such as aluminum, carbon steel, or stainless steel that is coated, plated, or sheathed with at least one layer of corrosion-resistant material [9].

The complexity of the electrochemical reactions in the sulfur electrode complicates an already difficult problem of material science. In the sulfur cell, the electrochemical potential, stoichiometry, and composition of the polysulfide melt vary periodically during cell operation and change the solubility, wetting properties, chemical reactivity, and viscosity of the reaction products [5]. Although researchers have tried numerous combinations of metals, nonmetals, alloys, and ceramics to develop a suitable material for the sulfur container [5], it remains a major unsolved problem of material science for $\mathrm{Na} / \mathrm{S}$ battery technology [10]. Current $\mathrm{Na} / \mathrm{S}$ cell designs use a chromium-containing layer as the primary corrosion barrier [10]. Chromium also seems to play an important but yet unknown role in the recharging of $\mathrm{Na} / \mathrm{S}$ cells; according to one expert, all the cells that work well use chromium for corrosion resistance [10]. A patent issued to Ford Motor Company [11] claims that continuous, controlled release of ions of chromium and other metals improves cell performance, reduces corrosion of corrodible metal current collectors, and prolongs cell life. A better understanding of the role of chromium (and other transitionmetal sulfides) in the electrochemistry of the sulfur electrode would also help in developing better corrosion-resistant materials to contain the sulfur electrode.

\section{$\mathrm{Na} / \mathrm{S}$ Cell Design}

All three principles of cell safety have been incorporated in the present generation of $\mathrm{Na} / \mathrm{S}$ cells. The $A B B ~ N a / S$ cell design has not changed very much since about 1985 as $A B B$ has focused its $R D \& D$ on battery engineering and battery-vehicle interfacing [10]. The major components of the ABB cell are a cylindrical metallic cell casing approximately $35 \mathrm{~mm}$ in diameter and $230 \mathrm{~mm}$ in length that also serves as the current collector, a sulfur electrode of graphite felt impregnated with sulfur, a tubular beta"alumina electrolyte surrounding an internal metal container and sodium (Figure 2). The cell is assembled by inserting the sulfur electrode in the cell casing, followed by the electrolyte tube containing the sodium electrode. An inert gas is used to force sodium onto the surface of the electrolyte at all states of charge. The electrolyte tube is closed off by a beta"-alumina-glass-alpha-alumina seal and an alphaalumina-metal thermocompression seal [3]. This cell design, designated A04 by ABB, has a capacity of 38 ampere-hours (Ah). Recently, ABB announced a A08 cell, which is similar in configuration to the AO4 cell but which has a slightly higher capacity [13]. 


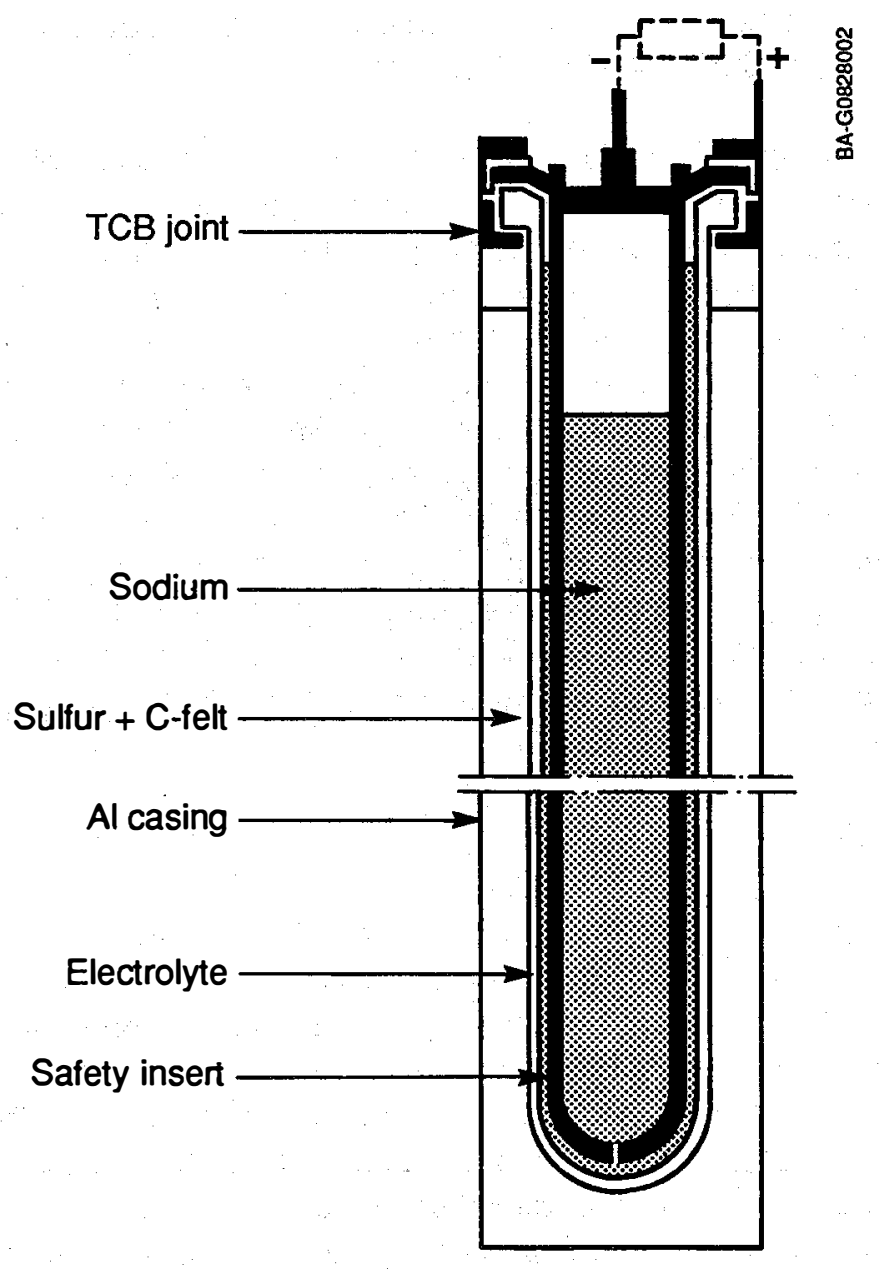

Figure 2. The $A B B$ cell design

Source: Ref. 24. 
The CSPL cell design contains essentially the same components as the ABB design but differs in geometry. The CSPL cell design, designated PB (Figure 3), is smaller than the ABB A04 cell, with a capacity of $10 \mathrm{Ah}$, and is shorter and can-shaped rather than tubular in shape. By decreasing the capacity of the cell, CSPL's design isolates small amounts of sodium (14.5 g) and sulfur (25 g) at the cell level and, similar to the ABB cell, incorporates important safety features into the cell design [9]. Although the geometry of the PB cell has remained essentially unchanged, its internal configuration has evolved over several design generations, resulting in both improved performance and safety. (See Molyneux et al. [14] for a history of CSPL's cell designs). To improve safety, internal design changes were made to limit the quantity of sodium available for reaction with sulfur if the electrolyte fractures, to restrict the flow of sodium to the site of the electrolyte fracture, and to protect the metal casing (and current collector) from corrosion by sodium polysulfides at high temperatures [9]. The bulk sodium is stored in a corrosionresistant safety tube, which has a small supply hole at its base. The safety tube fits within the beta"alumina electrolyte tube so that the annular distance between the two tubes is very small [10]. A small hole in the safety tube keeps the flow of sodium as small as possible and yet allows the minimum amount of sodium needed to maintain the electrochemical reaction.

\section{Cell Safety Testing}

The principal mechanisms of $\mathrm{Na} / \mathrm{S}$ cell failure include cracking of the electrolyte, degradation of the glass seal, corrosion of the container, and breaching of the metal-to-ceramic seals. Operating factors that impact these failure mechanisms include number of electrical and thermal cycles, time at operating temperature, depth of discharge, and cycling regime. Cells are tested for performance reliability and safety by subjecting them to electrical and thermal cycling. Cells are tested for both lifetime performance under normal operating conditions and for behavior under failure or extreme conditions.

\section{Life Testing}

Cells are electrically cycled under a variety of conditions in the laboratory. Over the past decade, the standard test regime has been a 3-hour, constant-current or voltage discharge and a 5-hour charge. Cells have also been tested using a number of other test regimes, including simulated on-road cycles such as the Federal Urban Driving Schedule (FUDS) [4] and a simplified version of FUDS called SFUDS. The standard test regime for electric vehicle (EV) applications is moving toward SFUDS.

There has been a steady improvement in results of service life testing at CSPL due to improvements over the past 5 years in the PB cell design. Test results show that safety performance of the PB cell design has also improved considerably between 1985 and 1989, with no breaches of the cell container or the seals in more than 2 years of life-cycle testing and abuse testing (described in the next section). Sandia National Laboratories (SNL) reported in 1990 that CSPL has had no infant mortality in the last 2400 PB cells, a failure rate of $0.0007 \% /$ cycle (measured to more than 1000 cycles) and a 0.0001 probability of a cell temperature exceeding $450^{\circ} \mathrm{C}$ [15]. Extensive life testing at the cell level has established the reliability of the PB cell design with virtual elimination of infant mortality on initial heating. The results of continuous testing for more than 3.5 years at CSPL to qualify cell components are summarized in Table 2. These results show that the major components of CSPL's central sulfur "TD" cell are stable and have qualified out beyond 5 years [7]. 


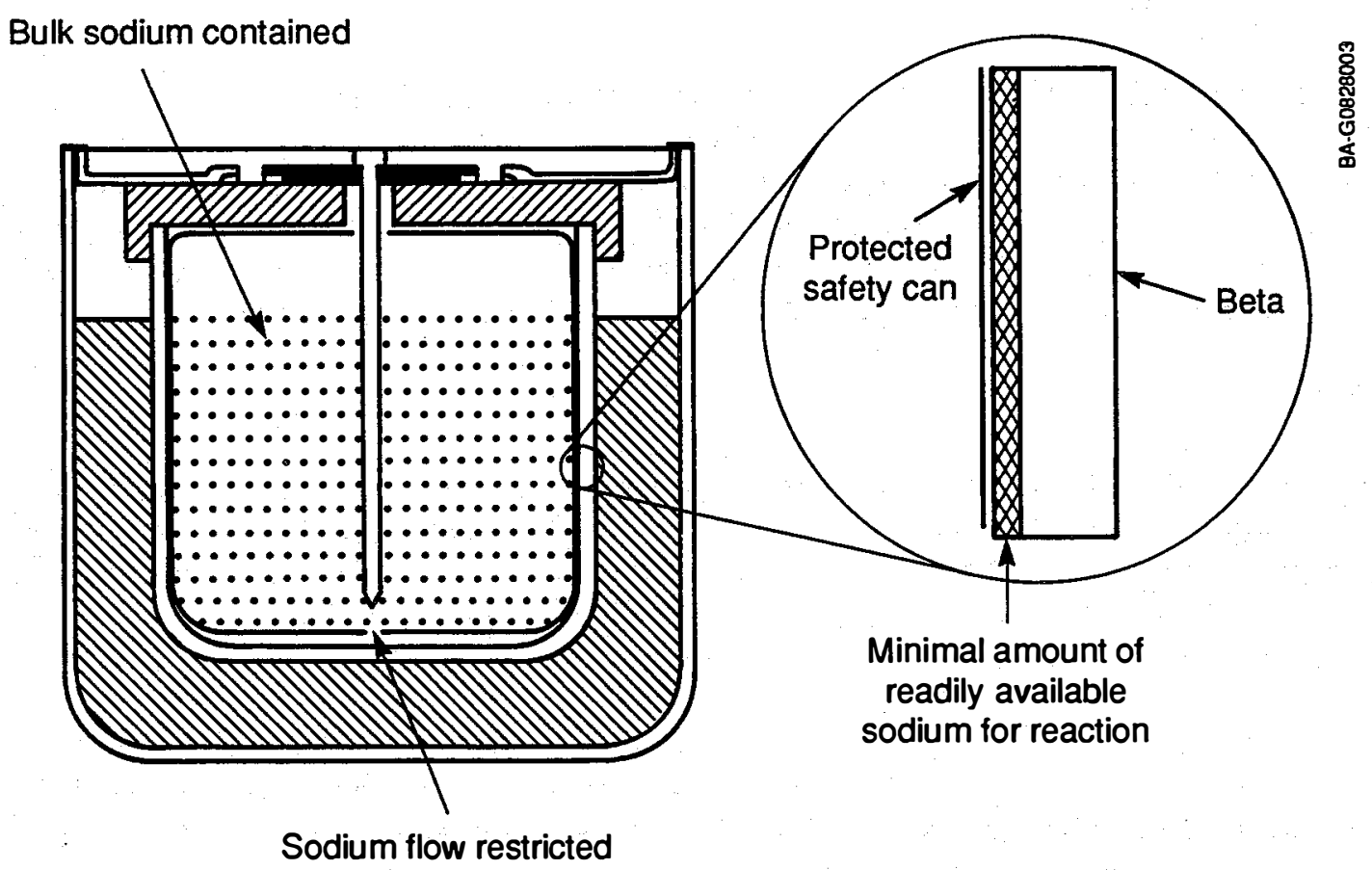

Figure 3. The CSPL cell design

Source: Ref. 15. 


\section{Failure Testing}

During failure testing, cells are deliberately damaged in order to assess their behavior under conditions far beyond normal operating conditions. The main failure testing method used at CSPL is to initiate cell failure by deliberately applying about $50 \mathrm{~V}$ to a fully charged cell [4]. This overvoltage leads to a catastrophic fracture of the ceramic electrolyte. Electric current is then passed through the cell to simulate failure in a battery environment, and the temperature exotherms generated by the direct mixing of sodium and sulfur are monitored by thermocouples attached to the cell case [16]. After the reaction of sodium and sulfur is completed and the cell is cooled down, its condition is determined through post-test examination, including X-ray radiography [16]. More than 100 failure tests of PB MkIII SF cells have been completed (as of April 1989) at CSPL, and no breaching has occurred [17]. Post-test examination by $\mathrm{X}$-ray radiography showed disintegration of the electrolyte and complete reaction of the electrodes [17].

Failure tests at CSPL comparing PB cells with and without safety features (primarily the metal safety tube containing and limiting the flow of sodium to the solid electrolyte, as described earlier) showed that these features moderate excessive temperature exotherms and prevent subsequent breaching of failed cells [16]. These tests were performed using 36-cell submodules by failing cells sequentially and monitoring the temperature exotherms of these cells. Most of the cells without safety features failed with maximum temperatures below $400^{\circ} \mathrm{C}$. The temperature in 3 of 23 cells tested exceeded $800^{\circ} \mathrm{C}$ and caused cell breaching. Damage from the breaching cells was limited to one or two adjacent cells, and there was no propagation of failure through the submodule [16]. In contrast, more than 30 tests on cells with safety features showed a mean temperature exotherm of $42^{\circ} \mathrm{C}$ (from a starting temperature of $350^{\circ} \mathrm{C}$ ), with a maximum temperature under $450^{\circ} \mathrm{C}$. None of these cells sustained cell breaching [16].

CSPL has examined the failure characteristics of the PB MkIII cells that breach during safety testing [16]. Once the temperature in these cells reached about $500^{\circ} \mathrm{C}$, the rise in temperature increased rapidly and caused breaching of the cell seal due to the combined effects of high-temperature corrosion and cell pressure. When the temperature of the cells test exceeded $525^{\circ} \mathrm{C}$, the pressure of the sulfur electrode became greater than that of the sodium electrodes, which were sealed at 610 Torr. It is at this point that breaching of the cell container is initiated in cells without safety features. To explore the sensitivity of cell breaching to relative electrode pressure, CSPL constructed nine cells in which sulfur pressure was higher than that of sodium at the normal operating temperature of $350^{\circ} \mathrm{C}$. When these cells were failure tested at this temperature, seven of the nine cells were breached immediately after fracture of the electrolyte, with accompanying large temperature exotherms. This experiment by CSPL showed the need to maintain the pressure of the sodium electrode above that of the sulfur electrode. Furthermore, an increase in the starting pressure over either electrode could cause large temperature exotherms after electrolyte failure. The experiment also showed the need to reduce the as-assembled pressure over both electrodes as much as is feasible. 
Table 2. Cell Component Stability

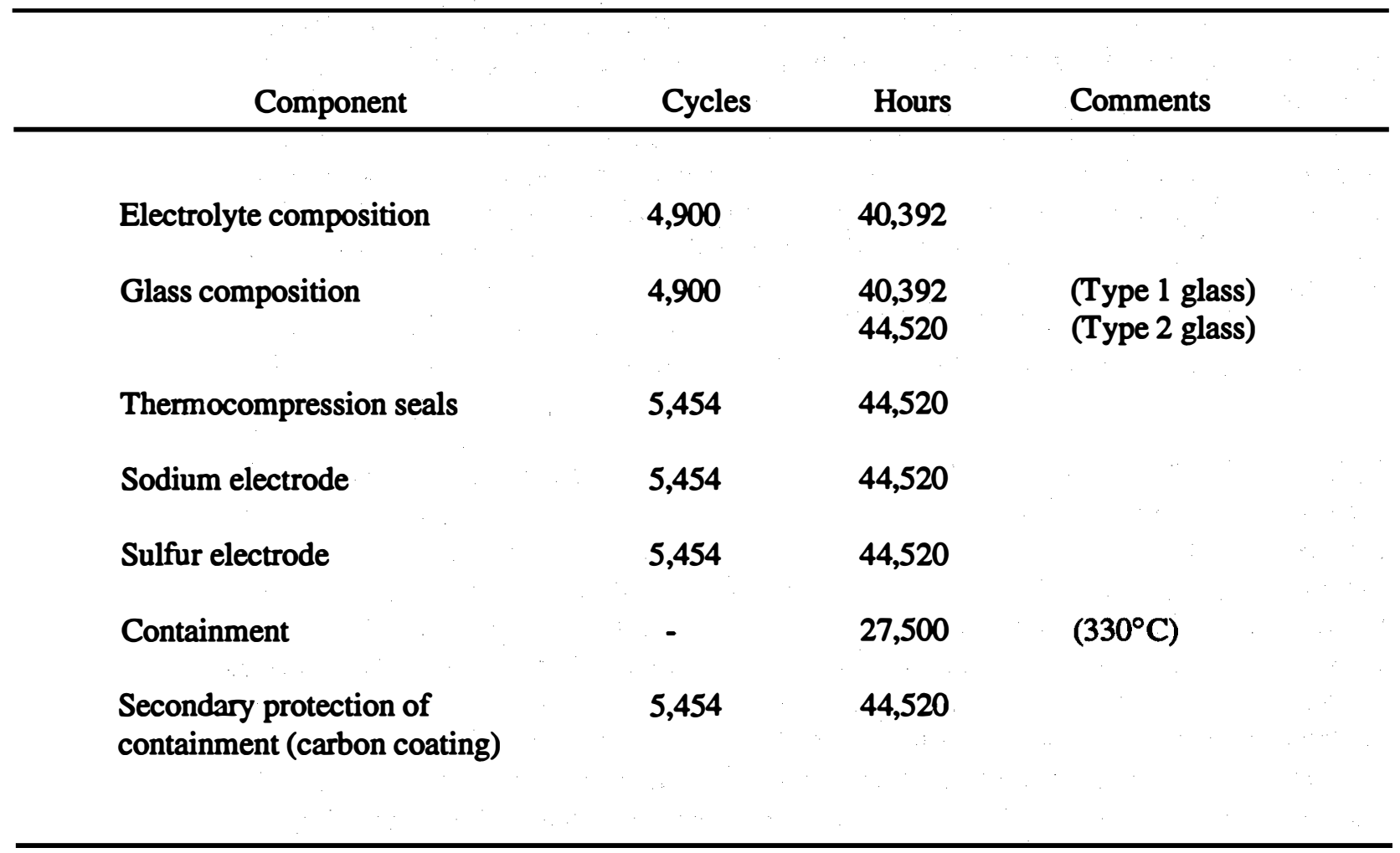

Source: Ref. 7. 
CSPL has also subjected PB cells to elevated temperature testing by deliberately overheating the cells [16]. These tests help to establish the limit for seal integrity and showed that the mean temperature at seal failure for the MkIII cell was $605^{\circ} \mathrm{C}$, at which point the sulfur vapor pressure reached 5320 Torr. The PB cell can maintain cell integrity to temperatures in excess of $600^{\circ} \mathrm{C}$, but the combined effects of polysulfide corrosion and sulfur electrode pressure generated on cell failure limits the maximum acceptable temperature to about $525^{\circ} \mathrm{C}$ [16].

\section{Thermal (Freeze-Thaw) Cycling}

The durability of $\mathrm{Na} / \mathrm{S}$ cells under thermal, or freeze-thaw (F/T), cycling is an important consideration for safety as well as reliability since most cell failures due to F/T involve fracturing of the ceramic electrolyte or breaking of seals [18]. These failure modes can cause leakage of reactants and pose a potential problem for safety. A Na/S battery will be subjected to numerous $\mathrm{F} / \mathrm{T}$ cycles during its expected 5- to 10-year lifetime due to, for example, low-demand periods for vehicle use or when the vehicle is inoperable for mechanical reasons. Although research, testing, and mathematical modeling of stress under F/T have greatly improved understanding of the problem, cell durability under F/T remains a major area of concem [18].

The factors that influence F/T failure rate include cell design, cell lifetime, rate of heating and cooling, and state-of-charge [18]. External factors such as shock and vibration could also influence F/T failure rate [18]. Many of the F/T failures in earlier cell designs that had a high ratio of length to diameter (aspect) were encountered on initial heat-up. These infant mortality failures can be avoided through proper cell design, fabrication, and break-in procedures. For example, CSPL's change in cell design from a large (150 Ah) tubular design with a high aspect to the smaller PB design with a low aspect improved $F / T$ performance by reducing the mechanical stresses on the electrolyte due to a cantilever effect. Also, some alpha-alumina-to-metal seal designs mechanically decouple the electrolyte from the container [18]. As mentioned in the previous section, improvements in cell design have virtually eliminated infant mortality on initial heating in the PB cell [15].

The more difficult F/T failures to prevent are those that occur after initial heat-up and breaking-in of the cell [18]. There has been extensive F/T testing on individual cells to determine the effects of depth-ofdischarge and thermal cooling/heating rate on solidification/melting of molten cell materials, the effects of multiple F/T cycles on component integrity and electrical performance of relatively new cells, the eff ect of one F/T cycle on the electrical performance of cells with many electrical cycles, and the effect of rapid cooling and heating rates on cell integrity [18]. These tests showed that PB cells possess "excellent intrinsic F/T durability at the cooling and heating rates that will be associated with an operational battery" [18]. Rapid heating and quench cooling of PB cells with subsequent electrical cycling showed that performance should not deteriorate as a result of thermal cycling [18]. There are much fewer data available in the literature on the F/T durability of $\mathrm{ABB}$ cells [12].

A major question remaining is the F/T durability of modules and batteries. The relatively few modules that have been subjected to $F / T$ testing show a higher and sometimes unacceptable cell failure rate than that observed for single-cell F/T testing [18]. In one case, post-test analysis showed many types of cell failure, including seal and container leakage and electrolyte fracture [18]. The lack of correlation between F/T testing results for individual cells and cells in modules raised questions concerning the F/T durability of the PB cell as well as test procedures used to determine F/T durability [19]. Since then it 
was determined that test procedures that did not allow the temperature to go low and long enough for freezing to take place were at fault [19]. Significant loss of battery capacity after a few F/T cycles is another indication that F/T durability may remain as an important problem [18].

Research and testing on F/T durability seem to indicate that $F / T$ cycling accentuates existing failure mechanisms and thus accelerates cell failure; it is no longer thought that $\mathrm{F} / \mathrm{T}$ cycling by itself causes electrolyte failure in PB cells [12]. There is still uncertainty on what critical parameter of cell history allows F/T cycling to accelerate cell failure. Possible parameters include time at temperature, number of previous F/T cycles, number of coulombs passed, and contamination of the electrolyte surface [18]. Other important questions include whether F/T failure generally occurs during freezing or thawing and the importance of heating and cooling rates near the melting point of the positive electrode materials [18]. Better understanding of how F/T cycling accelerates cell failure mechanisms may be important to improved cell safety.

\section{Safety Status of $\mathrm{Na} / \mathrm{S}$ Cells}

It is evident that RD\&D over the past decade on cell design and component materials have improved the reliability and durability of CSPL's PB cell to the point where cell safety per se is no longer a major concern under normal operating conditions. The major safety issue remaining for the PB cell is quality control as scale of production is increased. The Chloride-RWE pilot plant at Clifton Junction, UK, should begin to provide data on quality control of the PB cell in a production versus a laboratory environment. Uniformity of cell aging is a safety issue at the battery level [10] and is discussed below.

There is considerably less information on safety testing of the ABB cell. ABB seems to have focused its efforts on safety testing at the battery level. These safety tests are discussed below. Whether the safety established for individual cells in a laboratory environment is valid in a battery environment remains a critical question for further RD\&D.

\section{Battery Safety}

\section{Battery Design}

A Na/S battery consists of many hundreds of mechanically and electrically interconnected cells in an insulated enclosure that also houses a thermal management system for initial heat-up and waste heat control. The safe use of $\mathrm{Na} / \mathrm{S}$ batteries for vehicular propulsion begins with cell safety. Intensive RD\&D and testing have improved the reliability and durability of $\mathrm{Na} / \mathrm{S}$ cells to the point where CSPL has enough confidence in the technology to begin pilot-plant production of the PB cell design and where ABB felt it could concentrate on battery engineering using its A04 cell design. Although cell safety has been established through life and failure testing, the electrical, thermal, and mechanical environment at the battery level imposes additional safety questions and requirements. The fundamental premise of cell safety, isolating sodium and sulfur in small amounts and controlling the flow of sodium to the sulfur electrode, means that a large number of cells need to be interconnected to derive sufficient energy and power levels required for a battery. 
The safety strategy for batteries used at CSPL is to build in layers of protection from the cell up [20]. CSPL has constructed and tested a full-size battery containing 3584 cells in four similar quarter-unit modules [14]. The battery capacity was $300 \mathrm{Ah}$ at $230 \mathrm{~V}$, and it weighed $850 \mathrm{~kg}$ [4]. In the CSPL battery design, cells are assembled in banks that are wrapped in an electrically insulating blanket. These banks are assembled into quarter-battery modules, which in turn are placed in a thin, evacuated, double-wall, steel outer container. Each level of protection is designed to address the critical safety issue at that level of battery assembly - from double-wall containment of sodium at the cell level, to electrical insulation to protect against short-circuits at the bank level, to thermal insulation and double-wall containment at the outermost level.

The important components of battery design are electrical networking, electrical insulation, and thermal management [14]. A good electrical network design will accommode cell failure with minimal effect on battery performance. CSPL based its battery design on a four-cell string subunit with parallel interconnections at the ends of each string [14]. If a cell fails under such an arrangement, the remaining three cells in the string will be charged by parallel strings. One of the three cells will then develop a high effective resistance characteristic of $\mathrm{Na} / \mathrm{S}$ cells at top of charge because a cell in which sodium ions have been depleted from the sulfur electrode will no longer carry current in that direction [4]. The cell then acts as an open circuit device and prevents further current flow into the string. The string is inoperable, but other strings in parallel with it should continue to operate normally [14]. Each battery bank is individually monitored electronically to detect charge imbalance caused by cell failure or cell aging. Fully charged banks can be by-passed and current then flows at a reduced level to the other banks [4]. The monitoring system is interfaced with the charger and the vehicle controller to limit the maximum and minimum voltage across each bank [4].

The CSPL battery design using a large number of low-capacity cells provides a multitude of parallel paths and minimizes the effect of a cell failure on battery capacity. The effect of cell failure on battery safety is also minimized by the use of small, low-capacity cells because the amount of reactants that can escape from a failed cell is also small. The use of a small number of cells in a string also reduces the overvoltage (which is proportional to the number of cells in a string) experienced by the first cell to be recharged in the string [14] and thus reduces the likelihood of electrolyte fracture. Battery design must also minimize the likelihood of failure propagation by providing proper thermal and electrical insulation. For example, CSPL removed aluminum fins used in an earlier battery design for passive heat dissipation because of the potential for a high-temperature excursion to create alternate conduction paths for short circuits and to further propagate cell failures [12].

The thermal management system, the third major component of $\mathrm{Na} / \mathrm{S}$ battery design for safety, provides initial heat-up and controls waste heat while insulating the battery to maintain internal operating temperature and minimizing thermal hazard to the external environment. During normal operation, internal resistance losses will maintain operating temperature without additional heating [4]. The system must also maintain temperature uniformity within the battery enclosure because temperature gradients will affect cell performance. A typical temperature gradient between the inner and outer cells in prototype batteries is about $20^{\circ} \mathrm{C}$, which does not present a significant safety issue [12]. Because the temperature of the battery will rise with the rate of discharge, the rate of heat removal is an important consideration in keeping the battery within temperature specifications [21]. In some CSPL battery designs, a forced air cooling system was activated when the intemal battery temperature reached about 
$360^{\circ} \mathrm{C}$ [22]. If the temperature continues to rise, an electronic monitoring and control system signals the controller, and a reduction in power is initiated [22].

The outer thermal container keeps heat loss within an acceptable range, insulates the battery from external temperature extremes, and forms the final protective barrier between any leaking reactants and the external physical environment. The thin double-wall evacuated enclosure must withstand water and salt spray, mechanical shock and vibration, and impacts with road debris [4]. The vacuum insulation system must also be load bearing and should have a heat conductivity of $10^{-3} \mathrm{~W} / \mathrm{m}^{\circ} \mathrm{C}$ or lower [3]. The thermal conductivity of current vacuum insulating systems is about $0.004 \mathrm{~W} / \mathrm{m}^{\circ} \mathrm{C}$, and typical thermal loss from a $50-\mathrm{kWh}$ battery will be about $200 \mathrm{~W}$. This means that a battery can stand off-charge for up to 48 hours [4]. Better vacuum insulation enclosures could improve the safety of $\mathrm{Na} / \mathrm{S}$ batteries by potentially reducing the number and severity of F/T cycling.

The ABB battery that has undergone the most extensive testing is designated as the B-11. The B-11 consists of 360 A04 cells, with the most common configuration being six 60-cell strings with crossconnections every five cells [21]. The B-11 battery is an experimental battery designed for performance tests in EV applications and, depending on the cell configuration and electrical interconnection pattern, has a continuous power rating of $24-35 \mathrm{~kW}$ and weighs $200-280 \mathrm{~kg}$. Two B-11s would be used to propel a mini-van whereas three would be used for a full-size van. The battery uses replaceable cells and a conventional thermal plug to allow maintenance. Commercial versions of a smaller 10-kWh design (B120) will be simplified and have nonremovable cells, complete vacuum insulation, and a shape tailored for EV applications [21].

\section{Battery Failure Testing}

Two ABB prototype batteries, the B-11 and the B-06, have been safety-tested by ABB in cooperation with the German Technical Supervising Agency (Technischer Ueberwachungs-Verein, or TUV) and, based on these tests, $\mathrm{ABB}$ has obtained permission to operate $\mathrm{EVs}$ powered by $\mathrm{Na} / \mathrm{S}$ batteries on public streets in (then) West Germany without restrictions [21]. Similar approval has been obtained in Canada [1]. Data from the ABB-TUV tests are not available in the literature, but the test results show that the prototype batteries assembled by ABB based on the A04 cell design can meet German and intemational standards (DIN, ISO) as well as additional standards established by the TUV for safety in vehicular use. It should be noted that these safety tests were performed on the batteries themselves and not on vehicles equipped with $\mathrm{Na} / \mathrm{S}$ batteries.

The testing criteria for the TUV certification are listed in Tables 4 and 5. Fifteen of ABB's BO6 and B11 $\mathrm{Na} / \mathrm{S}$ prototype batteries were tested against the following criteria [23, 24].

- Vehicular crash simulation (sudden deceleration) - a B-11 battery was mounted on a carrier that was accelerated to about $50 \mathrm{~km} / \mathrm{h}$ and stopped in about $50 \mathrm{~cm}$. The resulting curve of velocity versus acceleration showed a maximum deceleration of $24 \mathrm{G}$ and a mean value of about $18 \mathrm{G}$ for 80 milliseconds, which is comparable to results in standard crash tests for passenger cars. Electrical cycling of the battery before and after the test showed no change in performance. 
o Deformation testing - the thermal enclosure of a B-06 battery was compressed $25 \%$ to induce breakdown of cells. The battery was not destroyed, and there was no release of active materials. However, many cells failed and an internal fire occurred.

- Electrical short-circuiting - both B-11 and B-06 batteries were also short-circuited by connecting the battery plugs by a lead with a resistance of about 2 milli-ohms. The currents increased to very high values (1200 to $1500 \mathrm{amps}$ ) but stopped because the internal connectors melted after a few seconds. The cells remained tight, and the temperature increase was within the acceptable range.

- Effects of a vehicle fire-a gasoline fire was set for 10 minutes underneath a B-06 battery. The change in temperature within the thermal enclosure was less than $10 \mathrm{~K}$ [3].

o Thermal shock-a hot battery was immersed into cold water. Only small leaks occurred in a few cells.

Based on the results of these tests, ABB maintains that the only safety issue that remains to be resolved is mishandling of the battery, for instance, overcharging with a high overvoltage [24].

\section{Battery Life-Testing}

Failure testing of prototype $\mathrm{Na} / \mathrm{S}$ batteries has shown that they can withstand extreme conditions to which they may be exposed. Sodium-sulfur batteries must also undergo life-testing to be shown to be safe under normal operating conditions, which requires long-term field testing under actual driving conditions. The first $\mathrm{Na} / \mathrm{S}$ battery for an EV was constructed in England in 1975 by the Electricity Research Council Centre and consisted of 960 interconnected 30-Ah, central- sodium cells [5]. The battery was installed on a Bedford van, and the van was driven on public roads to demonstrate that a $\mathrm{Na} / \mathrm{S}$ battery could power a vehicle. The van had a range of 60 to 150 miles, but the battery failed after only 20 cycles [5]. A number of other one-time applications of $\mathrm{Na} / \mathrm{S}$ to power vehicles are described by Sudworth and Tilley [5]. Since 1986, ABB batteries have been installed in 80 vehicles, and 20 of these vehicles powered by a B-11 battery, including a BMW, a Daimler-Benz 190, a VW Jetta, and a Chrysler mini-van, have accumulated more than $250,000 \mathrm{~km}$ of operation (as of July 1990) in urban conditions on highways [19].

In January 1989, CSPL delivered a 19-kWh, one-third battery module to Argonne National Laboratory (ANL) for testing. This module contained 960 PB cells and included a charger and a thermal management system [21]. The module was evaluated for 241 test cycles by ANL and performed satisfactorily over this number of cycles. The thermal management system maintained the battery within the operating temperature range of $330^{\circ}-360^{\circ} \mathrm{C}$ throughout the testing. The module showed a high initial discharge battery resistance after a full recharge, which limits available power for acceleration and can cause high charge voltages if regenerative braking currents are not limited [25]. 
Table 3. Program for Safety Tests on Sodium-Sulfur Batteries

Part 1: Normal Use

Item

Electrical insulation to ground

High voltage

High current

State of charge

External short

Surface temperature of thermal enclosure with/without leaks atthe vacuum insulation

High temperature

Vibrations (DIN IEC 68)

- $2 \mathrm{G}$ vertical

- $1 \mathrm{G}$ horizontal (both axes)

- 10 min at resonance frequency

- $5 \mathrm{~h}$ discharge current

\section{Criteria of Acceptance}

$\mathrm{R}>500 \mathrm{Ohm} / \mathrm{V}$

Protection should be guaranteed by battery control unit

Shown at the panel

Special insulation of current leads

Fuse

Maximum values are at specified points

on the outer battery casing

Protection should be guaranteed by

battery control unit and/or design of heaters

No ground faults

No cell failures

Source: Ref. 23. 
TP-4678

Table 4. Program for Safety Tests on Sodium-Sulfur Batteries

Part 2: Safety During/After Accidents

\begin{tabular}{ll}
\hline \multicolumn{1}{c|}{ Item } & \multicolumn{1}{c}{ Criteria of Acceptance } \\
\hline $\begin{array}{l}\text { Mechanical shock (crash) } \\
(20 \mathrm{G}, 70 \text { milliseconds) }\end{array}$ & No damage of battery or cells \\
$\begin{array}{l}\text { Deformation } \\
\text { (up to } 25 \text { percent, breakage } \\
\text { of cells) }\end{array}$ & $\begin{array}{l}\text { No external fire } \\
\text { Emission of sulfur dioxide acceptable }\end{array}$ \\
$\begin{array}{l}\text { External short } \\
\text { (bridging of plugs) }\end{array}$ & $\begin{array}{l}\text { No extemal fire } \\
\text { No emission of sulfur dioxide or other reactants }\end{array}$ \\
$\begin{array}{l}\text { Upside down } \\
\text { Buttery operation is not affected }\end{array}$ \\
\hline
\end{tabular}

Source: Ref. 23 
In May 1990, ANL received an 8-V, 300-Ah module from CSPL for both performance and life testing [26]. The module contained 120 cells configured into 30 parallel-connected strings of 4-series connected cells. The module uses the same cell design and handware assembly used in the full-sized battery system for the Ford ETX-II vehicle described below. After completing performance testing, ANL began life testing in October 1990. As of July 1991, the module has completed more than 500 [charge-discharge] cycles, while retaining about $91 \%$ of its initial capacity of 292 Ah (at a 3-hr rate).

In January 1990, CSPL delivered a full-sized battery composed of three 19-kWh enclosed modules for testing in the experimental Ford ETX-II vehicle. A ground fault (later determined to be caused by shipping damage and poor placement of heater wire leads) was detected after the battery was uncrated [19]. Limited testing of the battery before it was retumed to CSPL showed that the battery met the performance and physical requirements of the contract under which it was made [19]. The battery was repaired by CSPL, who also modified the thermal, electrical, mechanical, and electronic systems of the battery based on the results of the limited testing and evaluation of damage from shipping [15]. The battery was re-delivered to Ford in August 1990. The battery is now being tested at Idaho National Engineering Laboratory and has been at temperature and cycling for nearly 18 months [27].

In May 1990, ANL received a B-11 battery ( $90 \mathrm{~V}, 22 \mathrm{kWh}$ ) from ABB for performance characterization and life testing [26]. The battery has 360 cells (30 Ah each) in three series-connected sections, with each section containing eight parallel-connected strings of 15 series-connected cells. Life testing began after the battery had been operated for about 160 cycles to characterize performance. After an interruption in testing to repair an electrical connection and to disconnect a cell (and corresponding cells in each of the strings in that section) that had failed upon cooling (for the repair) and heating back to operating temperature, ANL resumed life testing; as of July 1991, the battery has retained about $89 \%$ of its initial capacity of $238 \mathrm{Ah}$ after more than 450 cycles. Moreover, the thermal management system of the battery has maintained the battery temperature within the operating temperature range $\left(330^{\circ}-350^{\circ} \mathrm{C}\right)$ for highrate discharges to $50 \mathrm{~W} / \mathrm{kg}$.

\section{Safety Status of $\mathrm{Na} / \mathrm{S}$ Batteries}

Prototype $\mathrm{Na} / \mathrm{S}$ modules and batteries have been tested under laboratory conditions for both performance and safety. Laboratory testing has, not surprisingly, been focused on performance since prototype batteries are few in number, expensive, and are tested to meet contractual specifications based on performance standards. Safety testing has been limited primarily to those conducted by ABB in qualifying the B-06 and B-11 battery prototypes for use in test vehicles in Germany. Batteries have not been safety tested in vehicles. Field trials of test vehicles have provided data and information on performance and evidence that vehicles powered by $\mathrm{Na} / \mathrm{S}$ batteries can be operated safely in urban driving conditions. Although a significant number of kilometers have been accumulated by vehicles using ABB batteries, these vehicles are experimental and, therefore, limited in number and driven under controlled conditions. 


\section{Conclusions and Recommendations}

Both failure testing and life-testing of cells have shown that the chemical and thermal risks implicit in the presence of sodium, sulfur, and sodium polysulfides have been satisfactorily mitigated by engineering and design at the cell level. These modes of testing, however, need to be combined to evaluate the hazards and risks posed by $\mathrm{Na} / \mathrm{S}$ batteries from cell failure over the lifetime of the battery. Predictions of battery life based on cell statistics have not been accurate because of the differences between bench and field tests and the difference between cycle life and calendar life. Cell testing is useful for ranking the effects of cell design changes; understanding of battery life requires testing of full-sized batteries [19].

Cell failure statistics derived from laboratory testing procedures show that failure rates, particularly those due to infant mortality, have been reduced. There is still a finite probability of cell failure, however, even under a laboratory testing environment for individual cells. Since attaining a zero failure rate is unlikely, especially at the battery level under actual operating conditions, the eff ect of infrequent, isolated cell failures on battery safety is an open question [12]. A failed cell in a battery environment is susceptible to corrosion and breaching of the cell container, particularly over the 5-10 year lifetime projected for commercial $\mathrm{Na} / \mathrm{S}$ batteries.

Commercial Na/S batteries will be enclosed in a vacuum insulating outer container and will, in effect, be maintenance-free. Individual cells cannot be tested and removed as they can be, for example, in ABB's B-11 prototype battery. Furthermore, spatial distribution of cell failures has a significant effect on battery performance as well as undeterminable consequences for battery safety. In other words, individual cells in a should not only have uniform properties to begin with, but they should also age at the same rate [10]. The safety of $\mathrm{Na} / \mathrm{S}$ batteries depends on the electrical and thermal functioning of thousands of individual cells and the electrical, thermal, and mechanical systems that control and house these cells. A comprehensive, long-term testing program of $\mathrm{Na} / \mathrm{S}$ batteries in vehicles under actual driving conditions is needed to demonstrate that the technology has evolved to a point where commercialization is possible.

Based on the discussion above, the following conclusions and recommendations can be made concerning the safety of $\mathrm{Na} / \mathrm{S}$ batteries.

1. The ABB tests and TUV approval based on these tests are not sufficient for U.S. Federal Motor Vehicle Safety Standards (FMVSS) acceptance for the following reasons:

- Only prototype batteries were tested

- Batteries were tested outside of a vehicle

- Battery safety tests consisted of simulations of a vehicle crashing, catching fire, and being submerged in water

- Testing results but not data have been released by $\mathrm{ABB}$ and TUV. 
2. The $A B B / T U V$ tests may be more useful for obtaining shipping regulations than for obtaining FMVSS certification.

3. The tests performed by ABB for TUV approval (deceleration, deformation, fire, thermal shock, electrical short-circuiting) should form a sufficient basis for safety testing of the battery for catastrophic accidents.

4. It is not possible at this time to determine the type, number, and test regimes needed to meet the FMVSS for Na/S-powered EVs, especially crashworthiness.

5. The DOE and DOT should work with industry, perhaps through the Vehicle Safety Sub-working Group of the Ad Hoc EV Battery Readiness Working Group, to develop a comprehensive test plan for $\mathrm{Na} / \mathrm{S} \mathrm{EVs}$ to meet, at a minimum, the applicable FMVSS requirements.

6. The number of batteries required for destructive testing both outside and in vehicles must be determined after the testing plan is developed, not before.

7. Vehicle safety cannot be considered apart from design requirements for EVs. One example is the impact of new glazing materials, such as electrochromic glass for improved heating and cooling efficiency, on the ability of EVs to meet the requirements of FMVSS No. 205 on glazing materials.

8. The issue of attaining a public perception of the safety of $\mathrm{Na} / \mathrm{S} \mathrm{EVs}$ will probably be very different from that of obtaining FMVSS certification. Battery testing outside of the vehicle may be very important, since public perception may focus on the most obvious difference between EVs and internal combustion vehicles. Long-term, day-to-day operating convenience and reliability will also affect the public's perception of safety. Comprehensive and widespread public information and demonstration programs will be critical.

9. Destructive testing and crash testing do not address the other important question of long-term safety under normal operating conditions. Questions about cell aging and the effects of isolated cell failures within a battery must be addressed in a long-term testing program. 


\section{References}

1. P.G. Patil et al., "Shipping, Use, and Disposal/Recycle Considerations for Sodium/Beta Batteries in EV Applications," Proceedings of the Beta Battery Workshop, Chester, England, June 12-14, 1990.

2. J.J. Cohrssen and V.T. Covello, Risk Analysis: A Guide to Principles and Methods for Analyzing Health and Environmental Risks, Washington DC: Council on Environmental Quality, 1989.

3. W. Fischer, "Sodium Sulfur Battery Accomplishments and Remaining Problems," presentation to Materials Research Society Conference, Boston, Nov. 28-Dec. 2, 1988.

4. M.F. Mangan, "Sodium Sulphur Batteries for Electric Road Vehicles," Proceedings, EVS9, Toronto, Nov.13-18, 1988.

5. J.L. Sudworth and A.R. Tilley, The Sodium Sulfur Battery, London: Chapman and Hall, 1985.

6. N.I. Sax and R.J. Lewis, Dangerous Properties of Hazardous Materials, 7th ed., New York: Van Nostrand Reinhold, 1989.

7. F.M. Stackpool and S. MacLachlan, "Corrosion Resistant Materials for Sodium Sulfur Cells," Proceedings: DOE/EPRI Beta (Sodium/Sulfur) Battery Workshop VII, Oct. 1988, 24-1 ff.

8. N.J. Magnani et al., Exploratory Battery Technology Development Report for FY90, SAND91-0672, April 1991.

9. N.J. Magnani et al., Exploratory Battery Technology Development and Testing Report for 1988, SAND89-3039, Oct. 1989.

10. J. Rasmussen, Beta Power, Inc., personal communication, Oct. 11, 1990.

11. U.S. Patent 4,767,684 (Aug. 30, 1988), "Method of Chargeability Improvement and Reduced Corrosion for Sodium-sulfur Cells," assigned to Carl R. Halbach. I am indebted to J. Rassmussen and J.W. Braithwaite for this reference.

12. J.W. Braithwaite, Sandia National Laboratories, personal communication, Oct. 4, 1990.

13. W. Fischer, "Status and Prospects of Sodium-sulfur High Energy Batteries," Proceedings, 26th IECEC, vol. 6, 80-87, Aug. 1991.

14. J. Molyneux et al., "Development and Testing of Sodium Sulfur Batteries for Electric Vehicle Applications," Proceedings, 22nd IECEC, 975-982, Philadelphia, PA, Aug. 1987. 
15. Sandia National Laboratory, Presentation at Electric Vehicle Program Laboratory Project Review Meeting, Argonne National Laboratory, Sept. 6-7, 1990.

16. F.M. Stackpool, "Cell Development-A Focus on Safety," Proceedings: DOE/EPRI Beta (Sodium/Sulfur) Battery Workshop VII, Oct. 1988.

17. F.M. Stackpool et al., "Sodium Sulphur Battery Development," Proceedings, IEEE 1989, 27652768.

18. J.W. Braithwaite et al., "Effect of Thermal Cycling on CSPL Sodium/Sulfur Cells," Proceedings: DOE/EPRI Beta (Sodium/Sulfur) Battery Workshop VII, Oct. 1988, 38-1 ff.

19. J.W. Braithwaite, Sandia National Laboratories,"Foreign Travel Trip Report Summary," July 12, 1990 (unpublished).

20. P. Binden, Beta Power, Inc., personal communication, Nov. 26, 1990.

21. M. Altmejd et al., "Sodium/Sulfur Batteries for EV Propulsion," Proceedings, IEEE, 1989, 27692774.

22. R.D. McDowall, Safety Issues Associated with the Testing of Sodium Sulfur Batteries, Internal Technical Report, PG-EHVP-90-064, EG\&G Idaho, Inc.

23. W. Dorrscheidt et al., "Safety of Beta Batteries," Proceedings: DOE/EPRI Beta (Sodium/Sulfur) Battery Workshop VII, Toronto, June 1-3, 1988, 46-1 ff.

24. W. Fischer and T. Shiota, "State of Development of Sodium Sulphur Traction Batteries at ABB and Powerplex," Proceedings, EVS 9, Toronto, Canada, Nov. 13-16, 1988.

25. W.H. DeLuca et al., "Performance Evaluation of Advanced Battery Technologies for Electric Vehicle Applications," Proceedings, 25th Intersociety Energy Conversion Engineering Conference, Reno, NV, Aug. 12-17, 1990, Paper No. 900051.

26. W.H. DeLuca et al., "Performance and Life Evaluation of Advanced Battery Technologies for Electric Vehicle Applications," SAE Technical Paper Series 911634, reprinted from Alternative Fuels in the Nineties (SP-876), Future Transportation Technology Conference and Exposition, Portland, OR, Aug. 5-7, 1991.

27. A.F. Burke, Laboratory Testing of the CSPL Sodium-sulfur Traction Battery for the ETX-II Vehicle, Report No. EGG-EP-96-88, Dec. 1991. 


\title{
Appendix A
}

\section{Chemical Hazards of Sodium-Sulfur Batteries}

\author{
Source: Sandia National Laboratories \\ Safe Operating Procedures for Sodium/Sulfur Battery Laboratories \\ July 11, 1990
}

I. Sodium

A. Sodium - Its Nature

Sodium ( $\mathrm{Na}$ ) is a soft, lightweight metal easily cut with a knife. It is so reactive that it does not occur in elemental form in nature but is widely distributed in stable compounds. In an inert atmosphere, freshly cut sodium has a pinkish bright metallic luster. In air, the cut surface forms a white or grey coating of sodium oxide, hydroxide, and/or carbonate. Nitrogen, argon, and helium are inert to sodium and can be used to backfill containers used to store sodium. Hydrocarbons, such as mineral oil, kerosene, xylene, toluene, etc., neither dissolve sodium nor react with it, and are commonly used as storage media for finely divided sodium particulates. Sodium metal is a good conductor of heat and electricity. Sodium requires special handling techniques to avoid fire, explosion, and personal injuries.

B. Sodium Hazards

1. General

Sodium is a powerful reducing agent. It reacts violently with water, forming sodium hydroxide (highly caustic and can cause serious burns) and hydrogen gas with release of considerable heat. The heat of the reaction with water is so great that in air or oxygen the released hydrogen invariably ignites with explosive violence.

2. Human exposure

Sodium causes severe thermal and alkali burns to body tissue, particularly to moist skin.

3. Other reactants to avoid:

- halogenated hydrocarbons (organic compounds containing bromine, chlorine, fluorine, and iodine: e.g., freon and trichloroethylene).

- many metal halides (e.g., Ti, P)

- hydrogen sulfide gas

- sulfur dioxide

- carbon dioxide at high temperature 
- soda acid or chlorinated fire extinguisher agents

- mineral acids

- metal oxides

The rates of the reactions cited in \#3 can vary widely with the particle size of the sodium and the temperature. The smaller the sodium particle and/or the higher the prevailing temperature the more rapid (or more violent) the reaction.

\section{Sulfur}

A. Sulfur - Its Nature

Sulfur(s) occurs both in the elemental state and in compounds, mainly as sulfides and sulfates; it constitutes $0.05 \%$ of the crust of the earth. Elemental sulfur is an odorless, tasteless, non-metallic, pale-yellow solid. Sulfur is insoluble in water, sparingly soluble in alcohol and ether, and soluble in carbon disulfide.

B. Sulfur Hazards

1. Human exposure

Sulfur dust is an irritant: inhalation of large amounts may cause inflammation of the nasal passages and mucous membrane.

Acute exposure to the skin may cause irritation, redness, and pain.

Acute exposure to the eyes causes irritation, redness, and pain.

2. Explosion/ignition:

Sulfur, especially as dust, ignites in air above $261^{\circ} \mathrm{C}$. It is stable under normal temperatures and pressures. The dust may be ignited by static electricity. Its flash point is $207^{\circ} \mathrm{C}$.

3. Other reactants to avoid:

- Aluminum (powder)

- Ammonia

- Bromates

- Activated carbon

- Metal powder (e.g., copper, iron, zinc)

- Hydrocarbons

- Strong oxidants (e.g., peroxides, chlorates, perchlorates, nitrates, permanganates 


\section{Sodium Tetrasulfide}

A. The Nature of Sodium Tetrasulfide

Sodium tetrasulfide occurs as glass-like, dark red pellets or fine yellow powder normally having a weak odor of hydrogen sulfide. It is strongly hygroscopic and strongly alkaline. Its melting point is $285^{\circ} \mathrm{C}$ and its decomposition temperature is greater than $300^{\circ} \mathrm{C}$. It is chemically stable at room temperature. It is extremely soluble in water and moderately soluble in ethanol.

B. Hazards of Sodium Tetrasulfide

\section{General}

- releases toxic sulfur dioxide upon buming.

- extremely corrosive if molten

2. Human exposure

- breathing dust causes severe burns of respiratory organs.

- aqueous solutions, vapors, and mists are extreme irritants to the eyes and skin; brief contact can result in severe damage.

- swallowing the liquid irritates the mouth, throat, and tissues of the gastrointestinal tract. If swallowed, this chemical will react with stomach acids to liberate toxic hydrogen sulfide gas.

3. Other reactants to avoid:

- mineral acids (can generate toxic, flammable hydrogen sulfide gas)

- oxidizing materials

IV. Sodium Sulfur Cells and Batteries

A. Chemical

1. The amount of sodium ( $\mathrm{Na}$ ) present in a cell ranges from $15 \mathrm{~g}$ to $90 \mathrm{~g}$. It is contained in a sealed stainless steel can with a ceramic header.

2. Under normal testing, contact with chemicals is extremely unlikely. 
3. In the event of a fire or accident, personnel can be exposed to sodium monoxide $\left(\mathrm{Na}_{2} \mathrm{O}\right)$, sodium hydroxide $(\mathrm{NaOH})$, sodium $(\mathrm{Na})$, and sulfur dioxide $\left(\mathrm{SO}_{2}\right)$.

a. $\mathrm{Na}_{2} \mathrm{O}, \mathrm{NaOH}$, and $\mathrm{Na}$ are highly alkaline materials that can cause irritation and rapid tissue destruction through chemical and thermal burns.

b. $\mathrm{SO}_{2}$ contacting the mucous membranes will cause formation of sulfuric acid resulting in severe tissue burns. Edema of lungs and respiratory paralysis may occur with high level exposures.

4. The following Permissible Exposure Limits (PEL's) have been established by OSHA:

a. Sodium Hydroxide $(\mathrm{NaOH}), 2.0 \mathrm{mg} / \mathrm{m}^{3}$

b. Sulfur Dioxide $\left(\mathrm{SO}_{2}\right), 5.0 \mathrm{ppm}$. 


\section{Appendix B}

\section{Toxicities and Reactivities of Chemical Elements and Compounds Potentially Associated with the use of $\mathrm{Na} / \mathrm{S}$ Batteries}

\section{Chromium (Cr)}

Chromium is poisonous to humans in low concentrations. Reported lethal doses have been as low as 71 $\mathrm{mg}$ per $\mathrm{kg}$ of body weight. It is also an experimental tumorigen and suspected carcinogen. Chromium is moderately reactive. Chromium powder will explode spontaneously in air.

\section{Hydrogen Sulfide $\left(\mathbf{H}_{2} \mathbf{S}\right)$}

Very poisonous gas in low concentrations. Doses as low as $5.7 \mathrm{mg}$ per $\mathrm{kg}$ of body weight have been known to be lethal. Concentrations of $800 \mathrm{ppm}$ have been lethal in 5 minutes. Lower concentrations are also lethal after a somewhat longer exposure. Hydrogen sulfide is an explosive gas, and is very dangerous when exposed to heat or flame. It ignites on contact with many substances. When heated to decomposition it emits $\mathrm{SO}_{\mathbf{x}}$.

\section{Sodium (Na)}

Although specific toxicity data are unavailable, it is fairly clear that ingestion of metallic sodium would cause severe burns. Metallic sodium is extremely reactive. It reacts exothermally, and frequently explosively, with water to yield hydrogen gas and sodium hydroxide (c.f.). It can react violently with a host of elements and compounds. When heated in air, sodium emits the toxic fumes $\mathrm{Na}_{2} \mathrm{O}$.

\section{Sodium Hydroxide (NaOH)}

Laboratory experiments have demonstrated that sodium hydroxide is lethal upon ingestion in quantities of approximately $500 \mathrm{mg}$ per $\mathrm{kg}$ of body weight. $\mathrm{NaOH}$ is a severe eye irritant, even in very low concentrations (e.g. 1\% solution). It is corrosive to skin, eyes and mucous membranes. Inhalation or ingestion of mists, vapors or dusts cause mentioned effects. Scarring and damage to the upper respiratory tract can occur upon inhalation. Sodium hydroxide is a strong base and is highly reactive. It can react violently with a host of elements and compounds, in some cases forming explosive compounds.

\section{Sodium Monoxide $\left(\mathrm{Na}_{2} \mathrm{O}\right)$}

This gas is moderately toxic upon inhalation or ingestion. It is corrosive to skin, eyes, and mucous membranes. In concentrations as low as 10 ppm it has demonstrated toxic effects. It is immediately lethal in concentrations above $1000 \mathrm{ppm}$. This substance is fairly unreactive, but can react violently with water. 


\section{Sodium Sulfide $\left(\mathrm{Na}_{2} \mathrm{~S}\right)$}

Sodium sulfide is mildly poisonous. It is highly corrosive to human tissue. When exposed to heat or flame, sodium sulfide is flammable. It reacts violently with water, and acts corrosively upon many metals.

\section{Sulfur (S)}

Elemental sulfur in solid form is virtually non-toxic and can be taken internally without injury. Inhalation of sulfur dust can irritate the eyes and mucous membranes of the respiratory passages. Sulfur presents a fire and explosion hazard because it has a low ignition temperature and a tendency to develop static charges. Sulfur become liquid at about $120^{\circ} \mathrm{C}$. Liquid sulfur has a low ignition point and can produce severe burns. The presence of hydrogen sulfide is also a possiblity when handling liquid sulfur. When heated to decomposition, sulfur forms the toxic gas $\mathrm{SO}_{\mathrm{x}}$. When burned in air, sulfur forms the toxic gas $\mathrm{SO}_{2}$.

\section{Sulfur Dioxide $\left(\mathrm{SO}_{2}\right)$}

This gas is poisonous by ingestion and inhalation. It is immediately life threatening in concentration of 400-500 ppm, but concentrations as low as $50 \mathrm{ppm}$ are considered to be toxic. This gas is also an experimental tumorigen and teratogen. Sulfur dioxide is moderately reactive, and forms sulfuric acid in the presence of water.

Sources: N.I. Sax and R.J. Lewis, Dangerous Properties of Hazardous Materials, 7th ed., New York: Van Nostrand Reinhold, 1989; Encyclopedia of Chemical Technology, vol. 22, 3rd ed., New York: John Wiley \& Sons, 1983. 